\title{
(Współ)myślenie w humanistyce. Literackie ekokształcenie w epoce antropocenu
}

\author{
(Co-)thinking in the humanities. \\ Literary eco-education in the Anthropocene era
}

\author{
Magdalena Ochwat \\ Uniwersytet Śląski w Katowicach \\ IORCID: 0000-0002-0178-165X
}

\begin{abstract}
In regard to the turn towards Earth in science and education, the ongoing Climate Youth Strikes and catastrophic forecasts for the future, the article is an attempt to introduce into school practice the trans-disciplinary trend called ecological humanities. The author of the article endeavored not only to apply new content to Polish language education - thanks to which it will be possible for students to reflect on their responsibility for the Earth - but also to recontextualize old texts by drawing attention to the relationship between man and environment. The basis for the mentality and educational changes is a designed bachelor's seminar, which involves students in the responsible eco-education.

Key words: ecological humanities, Anthropocene, Polish language, climate changes, consumerism, zero waste, ecology, responsibility for the Earth
\end{abstract}

Streszczenie: W związku z dokonującym się zwrotem ku Ziemi w nauce i edukacji, trwającymi Klimatycznymi Strajkami Młodzieżowymi, a przede wszystkim fatalnymi prognozami dotyczącymi przyszłości, artykuł jest próbą wprowadzenia do praktyki szkolnej transdyscyplinowego nurtu - humanistyki ekologicznej. Autorka zaaplikowała do edukacji polonistycznej nowe treści, dzięki którym uczeń może podjąć głęboki namysł nad odpowiedzialnością za Ziemię. Próbując odpowiedzieć na ekologiczne wyzwanie, autorka zrekontekstualizowała również szkolne lektury dawne, zwracając uwagę na nowe relacje człowieka ze środowiskiem. Podstawę zmian mentalnościowo-edukacyjnych stanowi zaprojektowane i opisane seminarium licencjackie, włączające studentów polonistyki w odpowiedzialne ekokształcenie.

Słowa kluczowe: humanistyka ekologiczna, antropocen, język polski, zmiany klimatu, konsumpcjonizm, zero waste, ekologia, odpowiedzialność za Ziemię

Nim przejdę do rozważań będących przedmiotem niniejszego tekstu, chciałabym zaznaczyć, że zawarte w nim treści nie dotyczą sposobów i metod uczenia, które uległy diametralnej zmianie w czasie, kiedy zostaliśmy „uwięzieni” w globalnym escape roomie ${ }^{1}$. Pandemia wirusa Covid-19

${ }^{1}$ Sformułowanie M. Tanaś z recenzji książki pt. Edukacja w czasach pandemii wirusa Covid-19. $Z$ dystansem o tym, co robimy obecnie jako nauczyciele (zob. Pyżalski 2020). W wolnym dostępie https://zdalnie.edu-akcja.pl (dostęp: 15.08.2020). 
wywarła wpływ na nasze relacje i zmusiła do używania narzędzi cyfrowych w obszarach życia, w których dotychczas nie były one przez nas wykorzystywane (np. nauczanie zdalne), a także zobligowała do posługiwania się nieznanymi dotąd aplikacjami (np. Zoom, Microsoft Teams). Odbyło się to raczej na drodze pospolitego ruszenia niż wskutek przemyślanych procesów przechodzenia z edukacji tradycyjnej na zdalną. Kształcenie online, w związku ze zmianami klimatycznymi, hodowlą przemysłową i rosnącym rynkiem dzikich zwierząt ${ }^{2}$, może w bliskiej przyszłości stać się jednym ze standardowych sposobów edukowania. Konsekwencją utraty bioróżnorodności w XXI wieku jest bowiem obniżenie odporności homo sapiens na choroby odzwierzęce, przed czym ostrzega Światowa Organizacja Zdrowia (zob. Bińczyk 2020, por. Giordano 2020, 47-48). Przez ostanie lata, po epidemiach eboli i SARS, uczeni informowali opinię publiczną, że w niedługim czasie nowy patogen zaatakuje ludzkość.

O niespotykanej wcześniej aktywności wirusów pisze Dahar Jamail - autor reportażu Koniec lodu. Jak odnaleźć sens w byciu świadkiem katastrofy klimatycznej, który łączy ich występowanie w krajach strefy umiarkowanej z ociepleniem planety:

Nie ma takiego płotu, który można by postawić, żeby je zatrzymać. Zaledwie w ciągu ostatnich dziesięciu lat wraz z trwającym wzrostem średnich temperatur przypadki chorób przenoszonych przez kleszcze, jak na przykład borelioza w stanie Maine, zaczęły występować trzydzieści razy częściej. Coraz bardziej prawdopodobny staje się wybuch dżumy w Dolinie Krzemowej w Kalifornii, a na równinach Kansas być może będziemy się borykać z tropikalnymi pasożytami żyjącymi we krwi (Jamail 2020, 203).

Na wzrastające zagrożenia uwagę zwraca również Slavoj Žižek w najnowszej książce Pandemia! Covid-19 trzęsie światem, w której filozof trafnie przekłada kryzys epidemiologiczny na ludzką egzystencję, pisząc:

będziemy musieli nauczyć się żyć dużo bardziej kruchym życiem, wśród ciągłych zagrożeń. Będziemy musieli zmienić całe nasze nastawienie do życia, do naszego istnienia jako istot żywych wśród innych form życia (Žižek 2020, 84).

Włącza on zmagania z Covid-19 w ramy ogólnej walki ekologicznej, a Bruno Latour na blogu „Posts from the Pandemic” stwierdza nawet, że nasze aktualne doświadczenia epidemiczne to „próba generalna” przed katastrofą klimatyczną (Latour 2020). Nie wystarczą już zatem tylko sprawnie działająca służba zdrowia, tarcze gospodarcze czy scentralizowane zarządzanie państwem, potrzebujemy przede wszystkim nowego sposobu myślenia o świecie jako całości. Artykuł ten stanowi zaledwie skromną próbę poszukiwania odpowiedzi na pytanie o sposób „splatania”3 świata w obszarze nauk humanistycznych stosowanych w szkole podstawowej. Próba ta jest ryzykowna z co najmniej dwóch powodów. Po pierwsze,

\footnotetext{
${ }^{2}$ K. Schmidinger, Koronawirus a konsumpcja produktów odzwierzęcych, https://www.schweitzer. pl/koronawirus-a-konsumpcja-produktow-odzwierzecych (dostęp: 15.08.2020).

${ }^{3}$ Figurę „splatania”, „wiązania” zapożyczam od Przemysława Czaplińskiego i Tima Ingolda. 
aktualne dokumenty oświatowe nie stwarzają wielu możliwości kształcenia w zakresie zachowań przyjaznych środowisku. Po drugie, w większości szkół nie dokonał się nowy zwrot ku Ziemi ${ }^{4}$, co - paradoksalnie - powinno stać się przyczynkiem do szkolnej dyskusji nad kondycją i sposobami traktowania planety.

W niniejszym tekście chciałabym podjąć temat odpowiedzialności ${ }^{5}$ za Ziemię i zamieszkujące ją istoty w kontekście postępujących zmian klimatu. Wartość ta w hierarchii etyki środowiskowej lokuje się na wysokiej pozycji, może być postrzegana w wymiarze jednostkowym, grupowym, pokoleniowym lub nawet planetarnym. Przedmiotem odpowiedzialności jest pozostawienie świata w takim stanie, aby mogły (prze)trwać kolejne pokolenia ludzi i innych organizmów żywych. Zadanie to przenosi nas w centrum problematyki moralnej, gdzie nauki humanistyczne - jak pisze Ryszard Koziołek - pełnią rolę „kulturowego zestawu ratunkowego”, „odmiany kształcenia obywatelskiego”, a z kolei dzięki nim możemy stać się „humanistami sygnalistami" (Koziołek 2019, 7-30). Ostrzegawczy gwizd sygnalisty ma wybudzać z letargu, skłaniać do wyjścia ze strefy komfortu, a przede wszystkim - zmuszać do myślenia o przyszłości. Rolę systemu wczesnego ostrzegania przed katastrofą pełniły nieprzerwanie do XX wieku kopalniane kanarki (Jamail 2020, 72). Na podstawie ich zachowania - stroszenia piór, omdleń czy w końcu śmierci - przewidywano, że zbliża się wybuch. Jeśli edukacja ma czujnik katastrofy, to jesteśmy nim my - humaniści. Dzięki kulturze możemy ćwiczyć siebie i innych w humanistycznych prognozach dotyczących przyszłości, myśleniu o planach zaradczych czy nagłej izolacji.

Problem ocalenia Ziemi traktuję szeroko. W jego ramy wpisuję zarówno krytykę antropocenu, rozpoznawanie śladów zmian klimatycznych (upalne lata i ciepłe zimy, pożary lasów), jak i działania ratujące przyrodę (zaprzestanie deforestacji, produkowanie mniejszej ilości odpadów, dawanie przedmiotom drugiego życia, protesty ekologiczne, a także angażowanie w konflikty o naturę). Postawa odpowiedzialności za losy planety i istot żywych to jedno z najważniejszych wyzwań, jakie stoją przed ludzkością w XXI wieku.

\footnotetext{
4 „Włochy staną się w tym roku pierwszym krajem na świecie, w którym uczniowie będą wprowadzać przedmioty związane ze zrównoważonym rozwojem i kryzysem klimatycznym, z materiałami włączonymi do regularnych lekcji, takich jak matematyka i geografia. Każda szkoła w Nowej Zelandii w tym roku będzie miała dostęp do materiałów o kryzysie klimatycznym przygotowanych przez wiodące agencje naukowe w kraju - w tym narzędzi dla studentów do planowania własnego aktywizmu i do przetwarzania swoich odczuć »ekologicznego niepokoju « w związku z globalnym ogrzewaniem". New Zealand schools to teach students about climate crisis, activism and 'eco anxiety'. „The Guardian”, 13.01.2020, https://www.theguardian.com/world/2020/jan/13/new-zealand-schools-to-teach-students-about-climate-crisis-activism-and-eco-anxiety (dostęp: 21.08.2020).

${ }^{5} \mathrm{O}$ „odpowiedzialności” jako istotnej wartości wychowawczej por. na przykład rozdział Wychowanie jako odpowiedzialność z książki Krzysztofa Maliszewskiego pt. Ciemne iskry. Problem aktualizacji pedagogiki kultury (Maliszewski 2013, 112-114). Zob. również rozdziały Wartości etyki środowiskowej, w tym Odpowiedzialność w monografii Włodzimierza Tyburskiego pt. Dyscypliny humanistyczne i ekologia (Tyburski 2013, 146-150) oraz artykuł Henryka Skolimowskiego pt. Wartości ekologiczne podstawa pokoju. Twórca ekofilozofii, Henryk Skolimowski, podkreśla taki rodzaj odpowiedzialności, „która wykracza poza nasze własne ego, odpowiedzialności za środowisko, za cała planetę, za inne istnienia ludzkie, za inne byty ożywione, za kosmos w całości - odpowiedzialność za wszystko" (Skolimowski 1989, 51).
} 
Imperatyw odpowiedzialności powinien podjąć każdy człowiek, ale przede wszystkim powinny mu podlegać nauka i edukacja humanistyczna, które dzięki kulturze, w tym literaturze, dysponują odpowiednimi narzędziami do wykształcenia nowego typu podmiotowości. Typ ten cechuje wysoki poziom bioświadomości; jest on oparty na doświadczaniu gniewu ${ }^{6}$ (afekt fundacyjny dla postawy walki z niesprawiedliwością względem środowiska), na samoograniczaniu się, powszechnej partycypacji ekologicznej, niekapitalistycznym podejściu do przyrody oraz chęci solidarnego ponoszenia kosztów rozwoju 7 . Jednocześnie w pokoleniu Grety Thunberg już wykształciła się wspólnota zdolna do nieposłuszeństwa ekologicznego, o którym pisali redaktorzy książki O jeden las za daleko. Demokracja, kapitalizm i nieposłuszeństwo ekologiczne w Polsce (Czapliński, Bednarek, Gostyński 2019).

Jestem świadoma, że najważniejszy dokument kształtujący edukację polonistyczną w szkole - podstawa programowa - już mocno obciążył nowymi treściami młodzież i nauczycieli. W niniejszym artykule proponuję wyjście poza kanon i sięgnięcie do fragmentów pochodzących z najnowszej literatury non-fiction. Czynię to z kilku powodów ${ }^{8}$. Jednak najważniejszym z nich jest fakt, że ten rodzaj pisarstwa, jako chyba jedyny obok cli-fi, nadąża za zmianami klimatycznymi ${ }^{9}$.

Nie proponuję jednak demontażu aktualnej listy lektur i budowania kolejnej jej wersji. Chciałabym raczej, wybierając odpowiednie fragmenty najnowszej literatury niefikcjonalnej, zmieniać perspektywę oglądu lektur uznawanych przez młodzież za anachroniczne i nieodpowiadające wyzwaniom stawianym przez XXI wiek. Cel takiego łączenia nie jest wszak nowy. To przede wszystkim sposób na doprowadzenie uczniów do „odkrycia”, że literatura dawna pozwala na dyskusję o współczesnych problemach świata, w tym o zmianach klimatu, roli przyrody, relacyjności świata. Owo spajanie różnych tekstów jest możliwe dzięki założeniu, iż czyta się „bardziej w poprzek niż wzdłuż historii literatury” (Barcz 2016, 9) i że ważny jest „splot” problemów, tekstów, narracji, czasów i form. „Splatanie otwartego świata" - używając tytułu pracy Tima Ingolda - (Ingold 2018) roślin, zwierząt, ludzi, przedmiotów stanowi nowy sposób myślenia w epoce antropocenu.

\footnotetext{
${ }^{6}$ Por. Markiewka 2020, zob. również M.C. Nussbuam, Gniew i wybaczenie. Uraza wielkoduszność, sprawiedliwość (Nussbaum 2016). Badaczka używa kategorii „gniew przemiany”, którą można najpełniej wytłumaczyć przez stwierdzenie: „To oburzające. Trzeba coś z tym zrobić”.

7 Cechy na podstawie książki $O$ jeden las za daleko. Demokracja, kapitalizm i nieposłuszeństwo ekologiczne w Polsce (Czapliński, Bednarek, Gostyński 2019, 16-21).

${ }^{8}$ Piszę o nich w artykule Reportaż $w$ świecie szkoły (Ochwat 2019).

$9 \mathrm{Na}$ potwierdzenie przywołam tytuły wydanych w ciągu ostatnich dwóch lat reportaży: Każdemu jego śmietnik. Szkice o śmieciach i śmietniskach (2019), Książka o śmieciach (Łubiński 2020), Smog. Diesle, kopciuchy, kominy, czyli dlaczego w Polsce nie da się oddychać? (Chełmiński 2019), Koniec lodu. Jak odnaleźć sens w byciu świadkiem katastrofy klimatycznej (Jamail 2020), Czarne złoto. Wojny o węgiel z Donbasu (Baca-Pogorzelska, Potocki 2020), Klimat to my. Ratowanie planet zaczyna się przy śniadaniu (Foer 2020) czy książka, która łączy esej z reportażem O czasie i o wodzie (Magnason 2020).
} 
(Współ)myślenie w humanistyce. Literackie ekokształcenie w epoce antropocenu

\section{Studenckie ekopraktykowanie, czyli o pewnym seminarium dyplomowym}

W obliczu braku systemowych rozwiązań dydaktycznych w zakresie humanistyki środowiskowej postanowiłam, w ramach seminarium dyplomowego na poziomie licencjackim, skłonić studentów do refleksji nad sposobami ocalenia Ziemi. Zasadza się ona na próbie odczytywania lektur szkolnych przeznaczonych dla uczniów szkół podstawowych przez krytyczny ogląd tradycji oraz odejście od paradygmatu antropocentrycznego na rzecz paradygmatu biowspólnotowego. Głównym celem zajęć stało się uzmysłowienie studentom roli lekcji języka polskiego, polegającej na inicjowaniu, wspieraniu oraz rozwijaniu zdolności myślenia o zmianach klimatycznych i wymieraniu gatunków.

Podczas zajęć seminaryjnych omawialiśmy kluczową dla nowego myślenia w dyscyplinie humanistycznej pozycję: Kultura jako czasownik. Sondowanie nowej humanistyki Ryszarda Nycza (Nycz 2017) oraz inne teksty teoretyczne dotyczące humanistyki ekologicznej: Ewy Domańskiej Humanistykę ekologiczna (Domańska 2013), tom 2 „Tekstów Drugich” z 2018 roku w całości poświęcony ekokrytce i specjalne wydanie „Tygodnika Powszechnego" z 2019 roku pt. Halo, tu Ziemia. Ponadto przedmiotem naszego zainteresowania stały się prace naukowe: Anny Barcz (Barcz 2016), Julii Fiedorczuk (Fiedorczuk 2015, 2019), Przemysława Czaplińskiego (Czapliński 2017, 2019), Anny Kronenberg (Kronenberg 2014) czy Anity Jarzyny (Jarzyna 2019, 2020). Zwrot ku Ziemi jest dziś obserwowany również w ramach innych dyscyplin naukowych: w filozofii, etyce środowiskowej, ekoestetyce, psychologii ekologicznej, ekoteologii i pedagogice ekologicznej (Tyburski 2013). Podpatrywaliśmy, jak postawy proekologiczne kreują różnorakie dziedziny nauk humanistycznych i inne dyscypliny.

Zasada pisania prac licencjackich była następująca: studenci najpierw wybierali pozatekstowy problem dotyczący środowiska (np. susza, głód, wycinka lasów, wykorzystywanie zwierząt, uchodźstwo klimatyczne, konsumpcjonizm), który „splatał” teksty szkolne z fragmentami najnowszych książek non-fiction. Prace finalizowały propozycje scenariuszy lekcji, implementujące do praktyki poczynione ustalenia teoretyczne.

Wśród tematów prac dyplomowych znalazły się:

- Kulturowe przedstawienia katastrofy czarnobylskiej w optyce dydaktyki szkolnej.

- Zmiany klimatyczne jako problem XXI wieku w edukacji polonistycznej omawiany na przykładach literackich związanych z kwestią lasów.

- Zero waste kontra konsumpcjonizm. Humanistyka ekologiczna na lekcjach języka polskiego.

- Dylematy XXI wieku na lekcjach języka polskiego na przykładzie problemu zmian klimatu oraz zagadnienia głodu. 
- Inny - czyli kto? O doświadczeniach uchodźczych na lekcjach języka polskiego.

- „Asperger to (...) dar”, czyli inny sposób patrzenia Grety Thunberg na świat. O zmianach klimatycznych, obojętności społeczeństwa i walce o naszą planetę - literatura zaangażowana w wyzwania XXI wieku.

- Nowa relacja zwierząt z człowiekiem w optyce edukacji polonistycznej.

\section{Autonomiczność i (bio)różnorodność lasów}

W szkole uczeń staje się aktywnym odbiorcą opowieści mitologizujących polskie lasy, które na różne sposoby wspierają, a czasem i powołują do życia narracje narodowe i tożsamościowe. Agata Agnieszka Konczal - autorka pracy Antropologia lasu. Leśnicy a percepcja i kształtowanie wizerunków przyrody w Polsce - praktyki te nazywa „leśną mitopraktyką" (Konczal 2017, 60). Przez taki właśnie konstrukt lasu interpretowana jest większość szkolnych tekstów literackich, ale najbardziej znaczącym, omawianym (we fragmentach i w całości) od 4 do 8 klasy utworem podejmującym przywoływaną tematykę jest Pan Tadeusz. Przedstawiana w nim przyroda jest unaradawiana („natura narodowa, więc piękna”), łączy się z uczuciami patriotycznymi, z pięknem ojczyzny ${ }^{10}$. Stan ten doskonale oddaje rozmowa Tadeusza i Hrabiego na temat drzew ojczystych oraz różnic pomiędzy niebem włoskim i polskim.

Przedmiotem analizy w szkole podstawowej są fragmenty epopei opisujące polowanie i grę Wojskiego na rogu. Sceny rozgrywają się w puszczy charakteryzującej się niezwykle bogatą roślinnością, co otwiera możliwość ich ekologicznej interpretacji. Takie spojrzenie nie jest niczym nowym w humanistyce, na co zwracałam uwagę studentów, już bowiem w latach 20. ubiegłego wieku na temat flory i fauny litewskiej wypowiadali się botanicy i przyrodoznawcy (Hryniewiecki 1956, Rostafiński 1921, Kapcia), zaś dziś w kontekście kryzysu klimatycznego pełni ono trochę inną rolę, nastawioną na „kształcenie wrażliwości ekologicznej i wychowanie człowieka w duchu empatii wobec innych form istnienia" (Domańska 2013, 31).

W czasie spotkania ze studentami omawialiśmy opis matecznika jako literackiego nośnika bioróżnorodności, symbiozy i ekosystemu, czyli widzenie lasu jako pewnej całości (od nasion do próchna), a także sprzeciwu wobec antropocentrycznej wizji świata, w którym istnieją prawa własności, kłótnie czy wojny. Fragment ten przedstawia świat pozbawiony panowania człowieka - nie stanowi również tła dla ludzkiej działalności.

Puszcza litewska jest miejscem niezwykle wielowymiarowym, tajemniczym, relacyjnym, jest ona domem (ekologia z greckiego oikos oznacza dom,

${ }^{10}$ Por. zadanie z podręcznika do klasy 4. „Uzasadnij, że w swoich opisach poetyckich przyrody twórca przebywający na emigracji wyraził zachwyt nad pięknem polskiej ziemi i swoją tęsknotę". H. Dobrowolska, U. Dobrowolska: Jutro pójdę w świat. Język polski. Podręcznik. Klasa 4, Kielce 2017, s. 113. 
domostwo) dla roślin i zwierząt od narodzin do śmierci. Dziki las ${ }^{11}$ jest wartością samą w sobie. Kwestię najważniejszą stanowi jednak nie tyle przywołanie Mickiewiczowskiego obrazu kniei, lecz jego zestawienie z reportażem Macieja Zaremby Bielawskiego Leśna mafia. Szwedzki thriller ekologiczny (Zaremba Bielawski 2014), w którym autor przedstawia zupełnie inny obraz lasów, a raczej „plantacji leśnych” usytuowanych w Szwecji. Są one równo posadzone, mają określony kształt, tworzą je drzewa jednego gatunku.

Współczesny las bez wątpienia oznacza postęp pod względem tak bezpieczeństwa, jak i higieny. Nie murszeje tam drewno w niehigienicznym mchu, alergik może spacerować niezagrożony brzozą i konwalią. To również raj dla dzieci - nie ma obawy, że mały Wilhelm potknie się o spróchniały pniak, naje nieznanych grzybów lub zabłądzi. Najbliższa droga przebiega zwykle nie więcej niż trzysta metrów dalej. Kto szuka ciszy, też będzie rad: spokoju plantacji nie zakłóca żaden dzięcioł ni piecuszek (Zaremba Bielawski 2014, 16).

Dzisiejszy las nie przypomina już mitycznych, tajemniczych, prastarych borów, w których rozbrzmiewały dźwięki owadów, ptaków, gdzie swoją bioróżnorodnością zaskakiwały nas drzewa. Zwróciliśmy uwagę na opisywany las i jego przeobrażenia mające miejsce w epoce antropocenu. Przechodzi on metamorfozę i jest inny niż las dziki, o ile w ogóle jesteśmy jeszcze w stanie o takim lesie myśleć. Wyhodowany obszar zielony to wytwór człowieka, obiekt przypominający raczej postlas ${ }^{12}$. Brakuje mu autentyczności, tajemniczości, bioróżnorodności i prawdziwości, zobrazowanych w Panu Tadeuszu.

Las w przedstawieniach kulturowych od wieków służył ludziom zarówno do celów gospodarczych, jak i jako miejsce relaksu i wytchnienia. Trzeba przyznać, że w wielu tekstach kultury drzewa stanowią dla bohatera pierwszoplanowego (człowieka) tło, rzadko traktowane są jako równoprawny uczestnik egzystencji ziemskiej. Wciąż obowiązuje jasna hierarchia - najpierw homo sapiens, później inne istoty - którą wyraźnie dostrzec można w lekturze $W$ pustyni i $w$ puszczy Henryka Sienkiewicza, gdy Staś i Mea decydują się na „dewastację” baobabu w celu stworzenia w nim kryjówki. Dziecięcy bohaterowie nazwali go nawet „Krakowem”, dając wyraz swemu przywiązaniu do polskości.

Problem sposobu wyzyskiwania drzew został podjęty również w baśni Hansa Christiana Andersena Choinka. Spotykamy się w niej z okrucieństwem władzy, jaką sprawuje człowiek nad drzewami szczególnie w czasie Bożego Narodzenia. Ten kierunek interpretacyjny poszerzaliśmy o jeszcze inne konteksty związane z klasyfikowaniem lasu jako zasobu sprowadzonego tylko do funkcji użytecznej człowiekowi, polegającej na produkcji tlenu, drewna czy oczyszczaniu wody (Konczal 2017, 260).

${ }^{11}$ Por. dziki las (nieużyteczny, bez kontroli i kontaktu z człowiekiem, „stan chorobowy lasu, brak pracy człowieka”) vs las naturalny (antyteza lasu dzikiego, las użyteczny i produktywny, wartościowy dla leśników). Konczal A.A., 2017, Antropologia lasu. Leśnicy a percepcja i kształtowanie wizerunków przyrody w Polsce, s. 245.

12 Dziś jesteśmy skłonni mówić o „postnaturze”, bo niczego już nie możemy uznać za czysto naturalne. „Postlas” posłużył mi do określenia lasu stworzonego przez człowieka w przeciwieństwie do lasów dzikich. 
Wymienione teksty czytane w szkole podstawowej studentka ${ }^{13}$, pisząca pracę licencjacką pt. Zmiany klimatyczne jako problem XXI wieku w edukacji polonistycznej omawiany na przykładach literackich zwiąanych $z$ kwestia lasów, proponuje zestawić z fragmentami książek Bohdana Dyakowskiego (Nasz las i jego mieszkańcy), Petera Wohllebena (Sekretne życie drzew, O czym szumia drzewa) oraz Urszuli Zajączkowskiej (Patyki, badyle). Są to antropomorficzne opowiadania ${ }^{14}$ i fascynujące historie o drzewach, które pokazują uczniom, że drzewa to istoty żywe, budujące między sobą relacje, zawierające przyjaźnie, opiekujące się potomstwem, komunikujące się ze sobą, cierpiące, świadome śmierci, i wreszcie - tworzące ekosystem, czyli społeczność drzew (trafnie ilustruje ją baśń Andersena). Peter Wohlleben porównuje istotę ich relacji do społeczności ludzkiej:

Dlaczego jednak drzewa są do tego stopnia istotami społecznymi, dlaczego dzielą się pokarmem z krewniakami z tego samego gatunku, a przez to tuczą konkurencję? Powody są identyczne z tymi, którymi kierują się ludzkie społeczności - razem łatwiej sobie radzić. (...) wiele drzew tworzy wspólnie ekosystem, który łagodzi skutki skrajnych upałów, gromadzi dużą ilość wody i produkuje bardzo wilgotne powietrze. W takim środowisku drzewa mogą rosnąć bezpiecznie i dożywać matuzalemowego wieku. By to osiągnąć, społeczność musi za wszelką cenę trzymać się razem (Wohlleben 2016, 13-14).

Problem ochrony lasów od kilku lat nie schodzi z pierwszych stron gazet. Ze względu na swoją aktualność temat ten może więc zachęcać uczniów do czytania, jak pokazały bowiem lekcje przeprowadzone przez seminarzystkę, młodzież chętnie rozmawiała o lasach za pośrednictwem proponowanych lektur i tekstów kultury.

\section{Cyrk bez zwierząt}

Anita Jarzyna w artykule $O$ czym myślę, kiedy myślę o zwierzętach w edukacji polonistycznej? Siedem odpowiedzi (Jarzyna 2020), wprowadza - na podstawie wniosków zamieszczonych w monografii Post-koiné. Studia o nieantropocentrycznych językach (poetyckich) (Jarzyna 2019) - swego rodzaju instruktażowe studia nad zwierzętami. Wskazuje ona na konstelacje zagadnień, zaczynając od diagnozowania źródeł antroponormatywnych stereotypów, przez sposoby ich przezwyciężania, a kończąc na alternatywnych reprezentacjach zwierząt i relacji z nimi. Łódzka badaczka podkreśla również, że tego typu lekcje powinny odbywać się w edukacji polonistycznej regularnie.

W przypadku prowadzonego przeze mnie seminarium studentka, analizująca w pracy licencjackiej problematykę relacji zwierząt z człowiekiem w optyce edukacji polonistycznej ${ }^{15}$, starała się przybliżyć wybrane przykłady bestialskiego traktowania zwierząt w ostatnich latach: trzymanie psów na

\footnotetext{
13 A. Lange, numer albumu: 321137.

14 „Las to nie tylko drzewa i różne gatunki roślin oraz zwierząt, ale przede wszystkim miejsce pełne opowieści”. Las to nie wielki magazyn drewna, (Machnik 2019, 41).

15 E. Kutaś, nr albumu 316560.
} 
łańcuchach, cierpienie koni dźwigających ciężary na turystycznych trasach, wykorzystanie małp, myszy czy szczurów w badaniach naukowych, cyrki z udziałem zwierząt, Festiwal Psiego Mięsa i inne. Analiza rzeczywistości była dla niej podstawą do postawienia pytania o to, czy kanoniczna literatura ma moc poruszania wyobraźni wobec okrucieństw dokonywanych na zwierzętach.

Ines Załęska-Olszewska zaleca ostrożność w tej materii, by nie doprowadzać do traumatyzowania dzieci. W artykule Animalna lekcja języka polskiego stwierdza, że doświadczanie przez zwierzęta śmierci z ręki człowieka może być zbyt drastyczne dla uczniów szkoły podstawowej ${ }^{16}$. Skoro jednak uczniowie analizują przewidziany przez podstawę programową dla klas 4-6 fragment dotyczący polowania w Panu Tadeuszu, dlaczego nie mieliby przyjrzeć się konsekwencjom (śmierci, ranom, cierpieniu), jakie płyną z tego typu archaicznych rytuałów uświęconych tradycją, prawem i religią ${ }^{17}$. I nie chodzi oczywiście o propagowanie idei zabijania, ale o krytyczną refleksję nad tak rozumianym elementem kultury narodowej ${ }^{18}$.

Jakie inne teksty można zaproponować uczniom szkoły podstawowej prócz Pana Tadeusza? Henryk Sienkiewicz w $W$ pustyni $i$ w puszczy przywołuje wiele gatunków zwierząt, zaczynając od ptaków, po psy, konie i zwierzęta afrykańskie - lwy, wielbłądy, antylopy, słonie, węże. Interesujący jest jednak nie sam obraz zwierząt, wyizolowany kadr skupiony na egzotycznych okazach, lecz ich usytuowanie względem człowieka.

W powieści, w jednym z pierwszych dialogów między dziecięcymi bohaterami, czytamy takie prowokujące do rozmowy zdania:

Patrz, lecą czerwonaki - zawołała nagle Nel. (...)

- Czerwonaki! Czerwonaki! - (...) Ach, gdybym miał strzelbę!

- Po cóż byś miał do nich strzelać? (Sienkiewicz 2006, 6).

Dzięki dalszej lekturze uczniowie dowiadują się, że czternastoletni Staś strzelał celnie do dzikich kaczek i egipskich gęsi, a jego marzeniem było polowanie na wielkie zwierzęta w Afryce. Ojciec, wprowadzając go w dorosłość, obiecuje mu również „nocą pójść na wilki”, motywuje do nauki, darując mu angielski sztucer i przybory przydatne myśliwemu. Jednak

${ }^{16}$ Referat prezentowany w czasie zdalnej konferencji naukowej pt. Wiek XIX na lekcjach języka polskiego. Literatura - język - kultura - historia (6-7 kwietnia 2020 roku). Zob. więcej http://polonistyka.uni.lodz.pl/konferencja-naukowa-wiek-xix-na-lekcjach-jezyka-polskiego-literatura-jezyk-kultura-historia-6-7-kwietnia-2020-roku (dostęp: 10.09.2020).

17 Warto zauważyć, iż polowanie to było nieudane, niezgodne ze sztuką łowiecką, pełne błędów, wykroczeń przeciwko dyscyplinie i bezpieczeństwu, które mogłoby, gdyby nie interwencja księdza Robaka, zakończyć się jeszcze większą tragedią (Mytych 2004,138). Temat ten zajmował zarówno teoretyków łowiectwa, jak i prawdziwych myśliwych, którzy uważali jego opis za nierealny, wręcz tragikomiczny (Dynak 1993, 1999, Maciejewski 1972).

18 Zob. Stanowisko Zakładu Dydaktyki Literatury i Języka Polskiego oraz Pracowni Innowacji Dydaktycznych Instytutu Filologii Polskiej Uniwersytetu im. Adama Mickiewicza w Poznaniu w sprawie projektu,, Podstawy programowej do języka polskiego” opublikowanego 30 grudnia 2016 roku. „Zdumiewająca jest decyzja umieszczenia wśród lektur obowiązkowych (kl. IV-VI) fragmentów Pana Tadeusza, zawierających opis polowania (...). Należy postawić pytanie: czy celem Autorów jest propagowanie idei zabijania zwierząt jako chlubnej tradycji narodowej?", http://legislacja.rcl.gov.pl/docs/50 1/12293659/12403175/12403178/dokument272274.pdf (dostęp: 10.09.2020). 
najbardziej wymownym fragmentem, pokazującym relacje „panowania”19 nad zwierzętami i wyższość człowieka w hierarchii form życia, jest postawa Stasia względem słonia:

wdrapał się po nim w mgnieniu oka na głowę i siadł słoniowi na karku.

- Aha - zawołał z góry na Nel — niech zrozumie, że to on musi mnie słuchać.

I jął klepać go dłonią po głowie, z miną władcy i pana (Sienkiewicz 2006, 155).

Język, którym posługuje się bohater, mówi wiele o jego stosunku do zwierząt - reprezentuje on zasadniczo optykę antropocentryczną. W innym miejscu Staś mówi do Nel tak: „Cofaj się, (...) bo inaczej muszę zastrzelić słonia” (Sienkiewicz 2006, 156), a kiedy jego mała towarzyszka zamartwia się głośnymi hukami wystrzałów, które rozsadziły skałę i uwolniły Kinga, Staś lekceważąco stwierdza: „To niech się przelęknie! (...) To mnie najmniej obchodzi" (Sienkiewicz 2006, 158). Powyższe wypowiedzi kontrastują ze słowami Nel („Dzień dobry, kochany słoniu!”) oraz z jej stosunkiem do zwierząt. I choć finalnie Tarkowski uwolnił Kinga, warto zwrócić uwagę na te dwa zupełnie różne podejścia. Lekcja polskiego realizowana w taki sposób może stać się ciekawym przyczynkiem do dyskusji na temat tego, czy troska o ludzi oznacza brak troski o zwierzęta, czy empatia może być międzygatunkowa oraz co łączy i dzieli współczesne i Sienkiewiczowskie podejście do kwestii traktowania zwierząt.

Prócz kontrastujących ze sobą głosów bohaterów warto przywołać fragmenty książek obrazujące zwierzęcą wrażliwość i emocje naszych braci mniejszych. Do omawianej lektury dobrze włączyć teksty o słoniach, które odnaleźć można w literaturze faktu: np. w książkach Carla Safina Poza słowami. Co myśla i czuja zwierzęta (Safin 2018) czy światowej sławy etologa - Marca Bekoffa Manifest zwierzat. Sześć powodów, żeby okazać więcej współczucia (Bekoff 2019). Sądzę, że połączenie literatury naukowej i fikcyjnej może pomóc zdefiniować nie tylko takie kategorie, jak „panowanie”, „władza”, ale przede wszystkim skłonić do zmiany w relacji człowiek-zwierzę.

Również w Quo vadis, powieści omawianej w klasach 7-8, odnajdziemy sporo fragmentów, w których przedstawiono krzywdę zwierząt i przemoc w relacjach ludzko-zwierzęcych. Celowe „uprowadzanie” zwierząt z naturalnego środowiska („słonie i tygrysy z Azji, krokodyle i hipopotamy z Nilu, lwy z Atlasu, wilki i niedźwiedzie z Pirenejów, zaciekłe psy z Hibernii, psy molosy z Epiru, bawoły i olbrzymie srogie tury z Germanii") (Sienkiewicz 1968, 490-491) i zmuszanie ich do czynów nieetycznych z punktu widzenia ludzkiego jest dla dzikich zwierząt po prostu zgodne z naturą. Zwierzętom nie dawano jednak jeść, lecz dręczono je, pokazując im zakrwawione kawałki mięsa, a po wykonanym show były bestialsko zabijane. Omawianie

${ }^{19}$ (Por. Bednarek 2017, 48-49). Papież Franciszek centralną pozycję człowieka nakazał łączyć nie z „panowaniem”, lecz ze zwiększoną „odpowiedzialnością”. Musimy dziś stanowczo stwierdzić, iż z faktu bycia stworzonymi na Boży obraz i nakazu czynienia sobie ziemi poddaną nie można wywnioskować absolutnego panowania nad innymi stworzeniami (Laudatio Si 2015, 45). W opisie stworzenia czytamy, że Bóg umieścił człowieka w ogrodzie Eden, „aby uprawiał go i doglądał” (Rdz 2, 15). 
tych fragmentów może stanowić punkt wyjścia do rozmowy o funkcji pełnionej przez człowiek w życiu zwierząt i odwrotnie - o roli zwierząt w życiu ludzi. Jak wyglądał świat zwierząt kiedyś i jak zmienił się dziś? Czy wciąż traktuje się je jako źródło rozrywki dla homo sapiens? Czy w analizowanych scenach literackich można odnaleźć „wspólne miejsca” pomiędzy cyrkiem Nerona a współczesnymi cyrkami?

W celu uruchomienia podczas lektury uczniowskiej empatii i ukazania, że XIX-wieczna lektura wiele i w sposób aktualny mówi o relacjach człowieka ze zwierzęciem, można zestawić ją np. z reportażem literackim Larsa Bergera Dobry wilk. Tragedia w szwedzkim zoo ukazującym, jak bardzo życie drapieżników w ogrodzie zoologicznym odbiega od życia w naturze. Literaturę tego typu można także wykorzystać do rozmowy o etycznych aspektach przetrzymywania zwierząt $w$ niewoli dla rozrywki ludzi. W tym celu można zaproponować uczniom podrozdział Nie rób cyrku ze zwierząt z książki Dariusza Gzyry Dziękuję za świńskie oczy. Jak krzywdzimy zwierzęta:

\begin{abstract}
Przedstawienia cyrkowe to często po prostu seanse dominacji nad słabszym, w otoczce zabawy. Dla dzieci, które je oglądają, to z pewnością swoista szkoła znieczulenia i lekcja, że zwierzęta są po to, żeby na żądanie i bez sprzeciwu zaspokajały nasze potrzeby, choćby drugorzędne, jak chęć rozrywki. Zwierzę w cyrku ma przecież zachowywać się tak, jak tego chce człowiek. Cyrk nie uczy rozpoznawania naturalnych potrzeb, uczuć i zachowań zwierzęcia. Przeciwnie, zakłada, że to, co naturalne, zwykłe, prawdziwe, niezaaranżowane, jest nieinteresujące lub mało wartościowe. Liczy się egzotyka, odmienność i wyjątkowość (Gzyra 2018, 276).
\end{abstract}

Także w niektórych podręcznikach szkolnych do języka polskiego znajdują się już teksty i polecenia umożliwiające refleksję na ten temat. I tak w podręczniku dla klasy szóstej NOWE Słowa na start! w rozdziale Spotkania $z$ natura uczniowie zapoznają się nie tylko z wierszami Wisławy Szymborskiej Jarmark cudów, Julii Hartwig Komunikat, ale i z fragmentem artykułu Olgi Kowalik Delfin człowiekowi człowiekiem (przedruk z „Przekroju” 2012, nr 15). Mogą się z niego dowiedzieć o „traktowaniu zwierząt jako surowca":

Warunkiem realnych zmian jest głęboka zmiana świadomości całych społeczeństw, przyzwyczajonych do traktowania zwierząt jako surowca- a nie jako istot, które czują i które w związku z tym mają prawo do godnego życia. To wymaga gruntownej zmiany nastawienia do wszystkich zwierząt, nie tylko tych wybranych. Zauważenia, że nie jesteśmy „panami stworzenia”, którzy mają prawo „czynić sobie ziemię poddaną", lecz jedynie jednym z wielu gatunków - na nieszczęście dla innych nieco bardziej inteligentnym (Klimowicz, Derlukiewicz 2018, 294).

\title{
Żona (nie)modna
}

We are in the beginning of mass extinction, and all you can talk about is money and fairy tales of eternal economic growth - takimi słowami Greta Thunberg na szczycie klimatycznym ONZ w 2019 roku krytykowała 
skutki wzrostu gospodarczego. Z pewnością potrzebujemy dziś nowej wizji świata, która bierze pod uwagę wszystkie aspekty globalnego kryzysu - środowiskowe, społeczne i ekonomiczne. To zresztą najpilniejsze wyzwanie stawiane przed humanistyką środowiskową i ekonomią wartości, używając kategorii Jerzego Hausnera (Hausner 2020). W sferze ekonomicznej nacisk kładzie się na ludzką działalność, która zaspokajając niezbędne potrzeby, chroni jednak środowisko naturalne. Akcentuje się zatem ekologiczne technologie produkcji, poszukiwanie odnawialnych i alternatywnych źródeł, recykling oraz konsumpcyjną powściągliwość (Gawor 2012, 57).

W tym kontekście podjęliśmy ze studentami refleksję nad tekstami ukazujacymi zgubna logikę konsumpcjonizmu i ideologii zysku. Myśleliśmy też o lekturach szkolnych, skłaniających do zastanowienia nad zmianq wartości stylu życia, nad „dobrobytem bez wzrostu”, używając tytułu książki Tima Jacksona, który stanowi rozwiązanie dla części problemów wynikających z ograniczonych możliwości planety. Spośród kilku tekstów szkolnych wybraliśmy: baśn Imbryk Hansa Christiana Andersena oraz satyrę Ignacego Krasickiego Żona modna i Opowieść wigilijna Charlesa Dickensa omawiane w klasach 7-820.

Tytułowa „żona modna” to obsesyjna konsumentka na miarę epoki oświecenia. Jej mania posiadania uwidacznia się w liczbie bagaży, pakunków i rzeczy zabieranych na wieś. Swoje cele życiowe definiuje w kategoriach posiadania („,karety na resorach, kucharzy cudzoziemców, pasztetników modnych, cukiernika, serwisu zwierściadlanego, figurki piękne z porcelany"21).Wiedzie życie ponad stan, oparte na francuskiej modzie, w którym nie ma miejsca na oszczędności, planowanie związane ze świadomością pracy, jaką trzeba włożyć, by zaspokoić jej potrzeby. Co prawda finalnie okazuje się, że bogactwo nie zapewnia szczęśliwego życia, jednakże ciągle zajmuje wysoką pozycję w piramidzie potrzeb. Wartość tego nieodkrywczego spostrzeżenia na temat majętności ma fundamentalne znaczenia dla refleksji na temat odpowiedzialności człowieka za eksploatowanie planety o ograniczonych możliwościach. Za globalny kryzys klimatyczny odpowiadają zwłaszcza ludzie zamożni - zużywają oni bowiem najwięcej wody, energii, produkują ogromne ilości odpadów.

Przy okazji omawiania Żony modnej z pewnością warto zapytać uczniów o dawne i współczesne pragnienia ludzi. Ciekawe mogą okazać się także uczniowskie odpowiedzi dotyczące ich rozumienia dobrobytu $w$ świecie o ograniczonych zasobach oraz próby odpowiedzi na pytanie o to, co będzie stanowiło $w$ przyszłości o bogactwie człowieka.

Proponuję, nie tylko jako trening interpretacyjny, ale element kształtowania postaw empatycznych, (roz)czytanie tego tekstu, opierając się na

${ }^{20}$ Problem ten został szerzej podjęty w pracy licencjackiej D. Brzuśnian, numer albumu 320621, tytuł pracy licencjackiej: Zero waste kontra konsumpcjonizm. Humanistyka ekologiczna na lekcjach języka polskiego.

${ }_{21}$ https://wolnelektury.pl/katalog/lektura/satyry-czesc-pierwsza-zona-modna.html (dostęp: 17.01.2020). 
(Współ)myślenie w humanistyce. Literackie ekokształcenie w epoce antropocenu

kategoriach ekologicznych, takich jak: rozwój, sprawiedliwość społeczna, odpowiedzialna konsumpcja, zużycie energii i zasobów oraz „poczucie winy uprzywilejowanych” (Bińczyk 2018, 69). Dzięki temu „eksperymentowi" możliwe jest odkrycie przez uczniów złożonej dynamiki wzajemnych relacji, np. korelacji pomiędzy dobrobytem jednych i nierównościami ekonomicznymi doświadczanymi przez innych.

Analizę oświeceniowego tekstu można aktualizować fragmentami z reportażu literackiego Życie na miarę. Odzieżowe niewolnictwo Marka Rabija (Rabij 2016). Celem połączenia tekstów jest skłonienie młodych do rozważenia kwestii tempa konsumpcji i pozbywania się przedmiotów, ale także zwrócenie uwagi na nierzadko okupiony niewolniczą pracą proces ich wytwarzania.

W tekście Imbryk Andersena podejmowaliśmy natomiast ze studentami temat darowania przedmiotom drugiego życia, zgodnego $\mathrm{z}$ zasadą zero waste. Biorąc pod uwagę fakt, iż wszystko jest ze sobą ściśle powiązane, zaproponowaliśmy taką oto drogę interpretacji tego tekstu w szkole. Na początku baśni uczniowie dowiadują się o "szlacheckim pochodzeniu” imbryka („dumny z porcelany, z której był zrobiony”; Andersen 1980, 183184), ważne jest, by zwracać ich uwagę na materiały (a nie na wartość materialną,) zgodnie z zaleceniami Tima Ingolda - ich certyfikaty prośrodowiskowe, informacje o tym, skąd pochodzą i czy ich produkcja nie wpływa na klimat. Dalej, uczniowie odczytują proces transformacji czajnika, na którą wskazują słowa: „jest się czymś jednym, a nagle staje się zupełnie czymś innym". Zdanie to sprowadzić można do naczelnej misji upcyclingu, czyli tworzenia przedmiotów użytecznych z rzeczy starych, zepsutych i niepotrzebnych. Stworzenie z imbryka "nowego” obiektu ogranicza nie tylko proces nabywania, ale i śmiecenia. Im więcej produktów jesteśmy w stanie przetworzyć (recykling), znaleźć im nowe przeznaczenie, tym mniej musimy kupować, wytwarzać, produkować, konsumować i utylizować. Dzięki filozofii zero waste, czyli zastosowaniu zasad recycle (przetwarzaj), reuse (użyj ponownie), a także reduce (ograniczaj) przedmioty otrzymują „drugie życie”. W zaproponowanej interpretacji baśni chodzi zatem o stosunek do przedmiotów - obdarzanie ich szacunkiem, ale i myślenie o kończących się zasobach naturalnych planety, na których wspiera się współczesna cywilizacja ludzka.

Pogłębioną ekologicznie perspektywę oglądu baśni Andersena uzyskamy dzięki zestawieniu jej z fragmentami takich reportaży literackich, jak Na marne i Mniej. Intymny portret zakupowy Polaków Marty Sapały oraz z tekstami ze zbioru Każdemu jego śmietnik. Szkice o śmieciach i śmietniskach. Pokazują one interesujące możliwości myślenia i mówienia o rzeczach i odpadach. Książka o śmieciach Stanisława Łubieńskiego definiuje z kolei, czym jest odpad i przybliża jego historię:

Odpadem według definicji nazywamy rzecz zbędną. Coś, czego się pozbywamy. Dziś pozbywamy się ubrań, mebli, sprzętów, książek głównie po to, by zrobić miejsce dla 
nowych, ale nie zawsze tak było. Dawniej przedmioty miały większą wartość, dlatego żyły dłużej. Człowiek nie pozbywał się niczego pochopnie, wiele śladów dawnych cywilizacji to prawdziwe, uczciwe śmieci. Śmieci, dla których już naprawdę nie było zastosowania (Łubieński 2020, 42).

Analiza proponowanych reportaży otwiera możliwość rozszerzenia namysłu nad skutkami szybkiej i nieprzemyślanej konsumpcji, czyli produkcji śmieci, które dziś stanowią jeden z największych problemów trapiących Matkę Ziemię.

\section{Nowy typ podmiotowości}

Kryzys klimatyczny, jak żaden inny współczesny problem, połączył w gniewie (na jednym z transparentów w czasie Młodzieżowego Strajku Klimatycznego napisano: przysZŁOŚĆ), niepokoju, buncie, wreszcie w protestach młodzież w wielu zakątkach świata. Urosły one do rangi fenomenu społecznego, dostrzeżono w nich potencjał zmiany.

W czasie strajku „Piątki dla przyszłości” (\#FridayForFuture) uczniowie opuszczali lekcje po to, by wyjść na ulice i strajkować przeciwko grabieżczej eksploatacji Gai ${ }^{22}$. Wśród młodych ludzi zaobserwowano nie tylko wysoki poziom świadomości ekologicznej oparty na samoograniczeniu, empatii środowiskowej, ale i zaangażowany sposób walki na rzecz zmiany na świecie. Rzesze nastolatków są bowiem pewne, dzięki znajomości raportów naukowych, także tych opracowanych przez Międzyrządowy Panel ds. Zmiany Klimatu (IPCC), że znajdują się w sytuacji absolutnie krytycznej. Postawę młodych nazywam ekologicznym nieposłuszeństwem, gdyż nie godzą się oni na bycie pokoleniem straconym. Ich przeżyciem generacyjnym staje się troska o przyszłość, aktywny udział w strajkach klimatycznych, protesty wobec praktyk stosowanych przez korporacje energetyczne, niezgoda na to, co mówią i robią politycy oraz pokolenie ich rodziców - dorosłych, którzy nie chcą zmieniać dotychczasowego życia.

Szkoła powinna być więc miejscem, w którym rozmawia się o przyszłości planety i globalnym ociepleniu, także za pośrednictwem literatury. Dlatego niepokojące są wypowiedzi nastolatków, którzy w reportażu Najpierw natura, później matura konstatują, iż:

nie przypominają siebie ani jednej lekcji o klimacie (...). Nikt nas nie uczy, jak odpowiedzialnie kupować, nikt nie mówi, z czego zrobione jest jedzenie i jak produkowane są ubrania. A to wszystko ma wpływ na klimat! (...). Gdyby szkoła uświadamiała wagę problemu, moglibyśmy wywierać jeszcze większy nacisk (Kojzar 2019, 38).

Odpowiadając więc na postulaty młodych ludzi, zastanawialiśmy się podczas zajęć seminaryjnych, o jakich nowych bohaterach-buntownikach walczących o przyrodę mówić na lekcjach polskiego i jak ich połączyć z analizą kanonicznych lektur? Jednym z nich jest Hans Afeldt, główny bohater przywoływanego już wcześniej reportażu Leśna mafia..., który stanął w obronie

${ }^{22}$ Nawiązuję do koncepcja Jamesa Lovelocka „Ziemia jako Gaja” - pojedynczy, samoregulujący się organizm. 
szwedzkich lasów. Rozmyślaliśmy też nad Janiną Duszejko - mścicielką walczącą o prawa zwierząt, a zarazem narratorkę w powieści Olgi Tokarczuk Prowadź swój pług przez kości umarłych. Uznaliśmy jednak bezsprzecznie, że najbardziej wyrazistą i zarazem realną bohaterką z racji zbliżonego do uczniów wieku będzie Greta Thunberg.

W sukurs przyszła nam jej biografia Sceny z życia rodzinnego. Strajk klimatyczny Grety, która ukazała się jesienią 2019 roku. Została napisana wspólnie przez aktywistkę i jej rodziców oraz młodszą siostrę Beatę. Książka zbudowana jest ze scen, które przedstawiają nie tylko nierówną walkę o klimat, ale i prywatne burzliwe życie Grety - zdiagnozowano bowiem u niej zespół Aspergera, który bohaterka tratuje jak dar²3, a później depresję. Jej siostra boryka się z kolei z ADHD, a rodzice starając się nadążyć za córkami, godząc codzienne funkcjonowanie z wyzwaniami ekologicznymi (Greta zmianę świata zaczęła od zmiany nawyków najbliższej rodziny). W proponowanej publikacji, na końcu książki, znajdują się również jej przemówienia, wpis z Facebooka dotyczący zjawiska hejtu i wystąpienie (z programu TEDx).

W związku z tym, że Podstawa programowa języka polskiego w szkole podstawowej dopuszcza wybór przez nauczyciela innych utworów literackich i tekstów kultury niż te przewidziane spisem lektur, a w preambule do niej napisano: „Szkoła (...) kształtuje postawę szacunku dla środowiska przyrodniczego, w tym upowszechnia wiedzę o zasadach zrównoważonego rozwoju, motywuje do działań na rzecz ochrony środowiska oraz rozwija zainteresowanie ekologią"24. Warto wprowadzić do edukacji polonistycznej kilka fragmentów ze Scen z życia rodzinnego..., zwłaszcza iż potrzebujemy nowych narracji, w tym opowieści o klimacie, i nowych bohaterów kształtujących wyobraźnię pokolenia urodzonego na początku XXI wieku.

Wybrałam dwie sceny z życia Grety, które wspólnie omawialiśmy na zajęciach seminaryjnych, zastanawiając się nad problematyką klimatyczną. Jedna ze scen rozgrywa się podczas lekcji i ukazuje obojętność młodych ludzi wobec problemu plastikowych odpadów zanieczyszczających Pacyfik. To przykład „martwej lekcji”, z której uczniowie nie wyciągnęli wniosków.

Fragment ten można odczytać jednak bardziej uniwersalnie - jesteśmy świadomi katastrofy klimatycznej, ale jednocześnie ludzka pycha i niczym nieograniczone życie sprowadzają nas na utarte ścieżki oraz skłaniają ku starym nawykom. Pokonanie tego dualizmu jest największym wyzwaniem stawianym przed ludzkością.

Klasa Grety oglądała podczas lekcji film o ogromnych ilościach śmieci, które pływają po morzach i oceanach. Na południowym Pacyfiku unosi się wyspa plastikowych

${ }^{23}$ „Niektórzy ludzie wyśmiewają się ze mnie z powodów moich dolegliwości. Ale asperger to nie choroba, tylko dar. Ludzie mówią także, że ponieważ mam aspergera, w żadnym razie nie powinnam podejmować takich działań. Ja jednak robię to właśnie dlatego. Ponieważ gdybym była „normalna” i społecznie przystosowana, wstąpiłabym do organizacji albo założyła własną. Skoro jednak w kontaktach społecznych nie radzę sobie najlepiej, wybrała taką drogę" (Ernman, Thunberg, Thunberg, Ernman 2019, 321).

${ }^{24}$ Podstawa programowa kształcenia ogólnego z komentarzem. Szkoła podstawowa. Język polski, https://www.ore.edu.pl/wp-content/uploads/2018/03/podstawa-programowa-ksztalcenia-ogolnego-z-komentarzem.-szkola-podstawowa-jezyk-polski.pdf (dostęp: 2.05.2020), s. 7. 
odpadów, które pod względem powierzchni jest większa od Meksyku. Greta cały ten film przepłakała. Widzę, że poruszył też jej koleżanki i kolegów. Przed końcem lekcji nauczycielka informuje wszystkich, że w poniedziałek ktoś inny przyjdzie na zastępstwo, ponieważ ona wylatuje na ślub - do Connecticut niedaleko Nowego Jorku.

- Wow, szczęściara z pani! - odpowiadają uczniowie.

Po wyjściu na korytarz żaden z nich nie pamięta już o plastikowej wyspie u wybrzeża Chile. Z puchowych kurtek z kapturami obszytymi futerkiem wyciągają iPhone'y, a ci, którzy już byli w Stanach Zjednoczonych, opowiadają, jakie fajne są tamtejsze sklepy. Inni dodają, że najlepsze zakupy można zrobić w Barcelonie, a w Tajlandii jest wprost bajecznie tanio. Ktoś inny chwali się, że ferie wielkanocne spędzi w Wietnamie. Grecie to wszystko nie mieści się w głowie (Ernman, Thunberg, Thunberg, Ernman 2019, 40).

Druga scena, wskazuje na różnice w sposobie podejścia do kryzysu klimatycznego i dotyczy konfliktu międzypokoleniowego. Pokolenie młodych protestuje przeciwko przypisywaniu im roli „ofiary”, z kolei dorośli chcą żyć tak, jak dotychczas. Młodzi mówią o „zniszczonych marzeniach” i „rozpaczy”, są zdezorientowani i zmartwieni tym, co robią ich rodzice. Szwedzka nastolatka zwraca również uwagę na to, że głos naukowców nie ma wpływu na społeczeństwa, gospodarki i polityków. A czas na zmianę powoli się kończy...

- To wy uratujecie świat. (...)

- Wszyscy nauczyciele twierdzą to samo - stwierdziła Greta.- „To wasze pokolenie ma uratować świat. To wy macie po nas posprzątać i załatwić, co trzeba". Każdy tak mówi, a potem wsiada do samolotu i leci na wakacje. „To wy macie uratować świat”. Tak, to już słyszałam. Byłoby jednak fajnie, gdybyście mogli nam w tym trochę pomóc. (...) tacy jak ja nie uratują świata, bo takich ludzi nikt nie słucha (...). Możemy najwyżej zacząć gromadzić pewną wiedzę, ale dzisiaj to jest bez znaczenia. Popatrz na naukowców. Nikt ich nie słucha, a nawet jeśli, to nie ma to już żadnego znaczenia, bo firmy zatrudniają całą masę własnych pseudoekspertów. (...) Prawdziwi naukowcy oponują, ale nikt ich nie słucha, bo firmy zdążyły rozesłać swoje komunikaty prasowe do połowy mieszkańców Szwecji. (...) Stworzyliście społeczeństwo, które ceni wyłącznie takie rzeczy, jak kompetencje społeczne, wygląd i pieniądze. Jeśli więc chcecie, żebyśmy uratowali świat, musicie zacząć od siebie (Ernman, Thunberg, Thunberg, Ernman2019, 148-149).

Po lekturze tych dwóch fragmentów jedna z seminarzystek ${ }^{25}$ zdecydowała o wprowadzeniu na lekcji języka polskiego biografii Grety, co wraz z propozycją przykładowych lekcji polskiego w szkole podstawowej stanowiło kanwę jej pracy dyplomowej. Zwróciła uwagę na fakt, iż spory pokoleniowe świetnie współbrzmią z konfliktami na przełomach epok (klasycy vs romantycy, romantycy vs pozytywiści) omawianymi w szkole średniej.

W szkole podstawowej studentka skonfrontowała szwedzką aktywistkę z postacią Adasia Niezgódki z Akademii Pana Kleksa Jana Brzechwy, lektury obowiązkowej w klasach 4-6. Greta przestała chodzić do szkoły i rozpoczęła

${ }^{25} \mathrm{~J}$. Łakota, numer albumu: 321144, tytuł pracy licencjackiej: Asperger to (...) dar, czyli inny sposóbpatrzenia Grety Thunberg na świat. O zmianach klimatycznych, obojętności społeczeństwa i sposobie walki o nasza planete - literatura zaangażowana w wyzwania XXI wieku. 
„Szkolny Strajk dla Klimatu” przed budynkiem szwedzkiego parlamentu, z kolei Adaś, któremu praktycznie nic się w życiu nie udawało, trafił do Akademii prowadzonej przez Pana Kleksa. Nastąpił przełom w życiu bohaterów - z niezdarnego chłopca Adaś stał się odważnym uczniem, a Greta, po silnej i długotrwałej depresji, liderką młodzieży. Uczniowie, wskazując na analogie i różnice w życiu postaci, mogliby zastanowić się nad tym, co przyniósł przyrodzie strajk Grety, a jaki wpływ na Adasia miało wstąpienie do Akademii.

Kolejnymi lekturami z kanonu szkolnego, dającymi możliwości podobnego odczytania, są: Opowieści z Narnii: Lew, Czarownica i Stara Szafa Clive'a Staplesa Lewisa (zestawienie postawy lwa Aslana z postawą Grety) oraz Mały Ksiażę Antoina de Saint-Exupéry’ego, utwór opowiadający przecież o chłopcu, który troszczy się o swoją planetę.

$\mathrm{Na}$ zakończenie refleksji o prowadzonym seminarium licencjackim warto dodać, że intencją moją nie było pokazanie perfekcyjnych lekcji polskiego. Chciałam raczej zwrócić uwagę studentów na to, iż edukacja polonistyczna, a w szerszym ujęciu - humanistyczna, może i musi mówić językiem lektur o rzeczach ważkich współcześnie. Kolejnym celem zajęć było zachęcenie studentów - przyszłych polonistów - do tego, aby starali się wychodzić poza przyjęte schematy odbioru dzieł literackich.

\section{Postscriptum}

Wspólne, moje i studentów, czytanie pozwoliło nam dostrzec potrzebę opowieści, interpretacji i refleksji, które na nowo splotą ludzi i naturę, człowieka z ziemią, homo sapiens z nieludzkimi istotami. Humanistyka środowiskowa dostarcza takich historii, wzmacniając ekologiczne odziaływanie na społeczeństwo. Cecilia Åsberg w wywiadzie Myślenie planetarne i nowa humanistyka mówi: „jest ważne, żeby wspierać naukę, jednocześnie rozwijać transformacyjny potencjał humanistyki" (Cielemęcka 2020, 34). Dyscyplina ta bowiem pomaga zrozumieć trudną sytuację biowspólnoty w czasie katastrofy klimatycznej, ale także niejednokrotnie doprowadza do ekologicznej przemiany człowieka (podkr. - M.O.).

O roli edukacji przemieniającej w czasie konferencji Dydaktyka polonistyczna i jej nauki mówił Tadeusz Sławek w wystąpieniu Wolne duchy i najmici. Edukacja jako kata-strofa. Wykorzystał do tego kategorię metanoi (z gr. przekraczanie tego, co jest; źródło kategorii za: Kołakowski 2014, 25). W teologii oznacza „nawrócenie”, a współcześnie o nawróceniu ekologicznym mówi papież Franciszek. Z kolei Leszek Gawor „proekologiczną metanoię" traktuje jako warunek sine qua non przetrwania cywilizacji ludzkiej. Bez niej nie wyzwolimy się z okowów antropocentrycznego myślenia. Pisze on tak: 
Metanoja, owocująca wrażliwością ekologiczną i imperatywnym nakazem jej praktykowania, oznacza ostateczne opuszczenie przez człowieka pozycji antropocentrycznych i wstąpienie na poziom poczucia holistycznej jedności z naturą, otwierającym przed człowiekiem nowy sposób percepcji świata (Gawor 2012, 55).

Rezultatem ekologicznej metanoi - twierdzi dalej Gawor - ma być pojawienie się nowego typu człowieka - homo ecologicus, który ma stać się istotą jakościowo lepszą od aktualnie dominującego homo sapiens. Spiritus movens przemiany powinna z kolei stać się edukacja, zwłaszcza zaś edukacja humanistyczna, której duch wyznacza drogę do dialogu i zmiany postaw.

\section{Bibliografia}

Baca-Pogorzelska Karolina, Potocki Michał, 2020, Czarne złoto. Wojny o węgiel z Donbasu, Wołowiec.

Barcz Anna, 2016, Realizm ekologiczny. Od ekokrytyki do zookrytyki $w$ literaturze polskiej, Katowice.

Bednarek Joanna B., 2017, „Na poczatku...”, czyli węzły relacji. Opisy stworzenia w Księdze Rodzaju, w: Czapliński Przemysław, Bednarek Joanna B., Gostyński Dawid, Literatura i jej natury. Przewodnik ekokrytyczny dla nauczycieli i uczniów szkół średnich, Poznań.

Bekoff Marc, 2019, Manifest zwierząt. Sześć powodów, żeby okazać więcej współczucia, Pluszka A. (przeł.), Warszawa.

Berge Lars, 2019, Dobry wilk. Tragedia w szwedzkim zoo, Kowadło-Przedmojska I. (przeł.), Wołowiec.

Bińczyk Ewa, 2018, Epoka człowieka. Retoryka i marazm antropocenu, Warszawa.

Bińczyk Ewa, 2020, Pandemia i rozszczelnianie zdrowego rozsadku. Szansa na demontaż 'business as usual'?, https://biennalewarszawa.pl/pandemia-irozszczelnianie-zdrowego-rozsadku-szansa-na-demontaz-business-as-usual (dostęp: 5.06.2020).

Chełmiński Jakub, 2019, Smog. Diesle, kopciuchy, kominy, czyli dlaczego w Polsce nie da się oddychać?, Poznań.

Czapliński Przemysław, Bednarek Joanna B., Gostyński Dawid, 2017, Literatura i jej natury. Przewodnik ekokrytyczny dla nauczycieli i uczniów szkół średnich, Poznań.

Czapliński Przemysław, Bednarek Joanna B., Gostyński Dawid, 2019, O jeden las za daleko. Demokracja, kapitalizm i nieposłuszeństwo ekologiczne $w$ Polsce, Warszawa.

Carl Safin, 2018, Poza słowami. Co myśla i czuja zwierzęta, Warszawa.

Domańska Ewa, 2013, Humanistyka ekologiczna, „Teksty Drugie: teoria literatury, krytyka, interpretacja", nr 1-2.

Dyakowski Bohdan, 2016, Nasz las i jego mieszkańcy, Poznań.

Dynak Władysław, 1993, Świat łowiecki w „Panu Tadeuszu”, w: Księga w 70. rocznice wydania „Ballad i romansów” Adama Mickiewicza, Kolbuszewski J. (red.), Wrocław. 
(Współ)myślenie w humanistyce. Literackie ekokształcenie w epoce antropocenu

Ernman Malena, Thunberg Svante, Thunberg Greta, Ernman Beata, 2019, Sceny $z$ życia rodzinnego. Strajk klimatyczny Grety, Siewior-Kuś A., Knockenhauer K., Łygaś W. (przeł.), Katowice.

Foer Jonathan Safran, 2020, Klimat to my. Ratowanie planet zaczyna sie przy śniadaniu, Wojtasik A. (przeł.), Warszawa.

Fiedorczuk Julia, 2015, Cyborg w ogrodzie. Wprowadzenie do ekokrytyki, Gdańsk.

Fiedorczuk Julia, 2019, Inne możliwości o poezji, ekologii i polityce. Rozmowy $z$ amerykańskim poetami, Gdańsk.

Gawor Leszek, 2012, Proekologiczna metanoia współczesnego człowieka jako warunek przetrwania cywilizacji ludzkiej, „Kultura i Wartości”, nr 4.

Giordano Paolo, 2020, W czasach epidemii, Draga S. (przeł.), Katowice.

Gzyra Dariusz, 2018, Dziękuję za świńskie oczy. Jak krzywdzimy zwierzęta, Warszawa.

Hryniewiecki Bolesław, 1956, Adam Mickiewicz a flora Litwy, Warszawa.

Ingold Tim, 2018, Splatać otwarty świat, Klekot E. (wyb. i oprac.) Kraków.

Jackson Tim, 2015, Dobrobyt bez wzrostu. Ekonomia dla planety o ograniczonych możliwościach, Polakowski M. (przeł.), Toruń.

Jamail Dahar, 2020, Koniec lodu. Jak odnaleźć sens w byciu świadkiem katastrofy klimatycznej, Paszkowska S. (przeł.), Warszawa.

Jarzyna Anita, 2020, O czym myślę, kiedy myślę o zwierzętach w edukacji polonistycznej? Siedem odpowiedzi, „Polonistyka. Innowacje”, nr 11.

Kapcia Barbara, Litewskie motywy lasu w Mickiewiczowskim doświadczeniu przestrzeni, http://elibrary.lt/resursai/Konferencijos/VU FF 28/referat\%20 Kapcia.pdf (dostęp: 08.08 2020).

Każdemu jego śmietnik. Szkice o śmieciach i śmietniskach, 2019, Wołowiec.

Kojzar Katarzyna, 2019, Najpierw natura, potem matura, „Non/fiction. Nieregularnik Reporterski”, nr 2/(6).

Kołakowski Leszek, 2014, Jezus ośmieszony. Esej apologetyczny i sceptyczny, Kraków.

Konczal Agata Agnieszka, 2017, Antropologia lasu. Leśnicy a percepcja i kształtowanie wizerunków przyrody w Polsce, Warszawa.

Kowalik Olga, 2012, Delfin człowiekowi człowiekiem, „Przekrój”, nr 15.

Koziołek Ryszard, 2019, Wiele tytułów, Wołowiec.

Kronenberg Anny, 2014, Geopoetyka jako przykład zielonego czytania i pisania, „Teksty Drugie: teoria literatury, krytyka, interpretacja”, nr 5 (149).

Las to wielki magazyn drewna. Z Peterem Wohllebenem rozmawia Paulina Machnik, 2019, w: O jeden las za daleko. Demokracja, kapitalizm i nieposłuszeństwo ekologiczne w Polsce, Czapliński Przemysław, Bednarek Joanna B., Gostyński Dawid, Warszawa.

Latour Bruno, 2020, Is This a Dress Rehearsal?, https://critinq.wordpress. com/2020/03/26/is-this-a-dress-rehearsal (dostęp: 15.08.2020). 
Łubiński Stanisław, 2020, Książka o śmieciach, Warszawa.

Maciejewski Jarosław, 1972, Dyplomatyka i łowy, w: Mickiewicza wielkopolskie drogi, Poznań.

Magnason Andri Saner, 2020, O czasie i o wodzie, Godek J. (przeł.), Kraków.

Maliszewski Krzysztof, 2013, Ciemne iskry. Problem aktualizacji pedagogiki kultury, Toruń.

Markiewka Tomasz S., 2020, Gniew, Wołowiec.

Myślenie planetarne i nowa humanistyka. Rozmowa Olgi Cielemęckiej z Cecilia Åsberg, 2020, „Czas Kultury”, nr 2.

Mytych Beata, 2004, Poetyka i łowy: o idei dawnego polowania $w$ literaturze polskiej XIX wieku, Katowice.

New Zealand schools to teach students about climate crisis, activism and 'eco anxiety', „The Gurdian”, 13.01.2020, https://www.theguardian.com/ world/2020/jan/13/new-zealand-schools-to-teach-students-about-climatecrisis-activism-and-eco-anxiety (dostęp: 21.08.2020).

Nussbuam Martha C., 2016, Gniew i wybaczenie. Uraza wielkoduszność, sprawiedliwość, Kolczyńska J. (przeł.), Warszawa.

Nycz Ryszard, 2017, Kultura jako czasownik. Sondowanie nowej humanistyki, Warszawa.

Ochwat Magdalena, 2019, Reportaż w świecie szkoły, w: Literatura polska $w$ świecie, t. 7, Reportaż w świecie - światowość reportażu, Katowice.

Rabij Marek, 2016, Życie na miarę. Odzieżowe niewolnictwo, Warszawa.

Rostafiński Józef, 1921, Las, bór, puszcza, matecznik jako natura i baśń w poezji Mickiewicza, Kraków.

Sapała Marta, 2014, Mniej. Intymny portret zakupów Polaków, Warszawa.

Sapała Marta, 2019, Na marne, Wołowiec.

Skolimowski Henryk, 1989, Wartości ekologiczne podstawa pokoju, w: Zielona antologia, Gliwice.

„Teksty Drugie: teoria literatury, krytyka, interpretacja”, 2018, nr 2 (temat przewodni numeru - ekokrytyka).

„Tygodnik Powszechny”, 2019, wydanie specjalne Halo, tu Ziemia.

Tyburski Włodzimierz, 2013, Dyscypliny humanistyczne i ekologia, Toruń.

Wohlleben Peter, 2016, Sekretne życie drzew, Kochanowska E. (przeł.), Kraków.

Wohlleben Peter, 2018, O czym szumiq drzewa, Kochanowska E. (przeł.), Kraków.

Zajączkowska Urszula, 2019, Patyki, badyle, Warszawa.

Zaremba Bielawski Maciej, 2014, Leśna mafia. Szwedzki thriller ekologiczny, Warszawa.

Žižek Slavoj, 2020, Pandemia! Covid-19 trzęsie światem, Maksymowicz-Hamann J. (przeł.) Warszawa. 


\section{O Autorce}

Magdalena Ochwat - dr, Instytut Literaturoznawstwa, Interdyscyplinarne Centrum Badań nad Edukacją Humanistyczną, Wydział Humanistyczny, Uniwersytet Śląski w Katowicach.

Jej zainteresowania naukowe skupione są na edukacji polonistycznej, wykorzystaniu w kształceniu reportaży literackich oraz społecznej odpowiedzialności lektur szklonych. Interesuje się wyzwaniami XXI wieku: globalnymi kryzysami, migracjami, zmianami klimatycznymi i wielokulturowością. Redaktor naczelna czasopisma „Z Teorii i Praktyki Dydaktycznej Języka Polskiego" i koordynator programu dla nauczycieli polonistów „Uniwersytet Polonistów” w ramach projektu POWER. 
